\title{
Kontribusi Komitmen Kerja Dan Iklim Sekolah Terhadap Kepuasan Kerja Guru Sma Kecamatan IV Jurai Pesisir Selatan
}

\author{
Muhammad Sahnan, Mahyudin Ritonga \\ Universitas Bung Hatta, Universitas Muhammadiyah Sumatera Barat, Indonesia \\ mubammadsabnan72@gmail.com, mabyudinritonga@gmail.com
}

\begin{abstract}
This study aims to explore the contribution of work commitments and school climate on teacher's job satisfaction. This research uses correlational methods that were analyzed with correlation and regression techniques. The result showed that work commitments was contribute significantly to job satisfaction of teachers. This means that the work commitments could be used as a predictor for the teacher's job satisfaction. Then school climate contribute significantly to teacher's job satisfaction also. This results means that the school climate can be used as a predictor for the teacher's job satisfaction. Commitment to work and school climate were contribute significantly to teacher's job satisfaction. Teacher's job satisfaction is influenced by work commitments and school climate, either individually or jointly. Further, high commitment and also supported by a school climate create the conducive and improve the teacher's job satisfaction. Commitment to work and school climate are two factors which are very important because it can affect the job satisfaction, but there are other factors that are believed to take effect on teacher's job satisfaction.
\end{abstract}

Keywords: work commitment, school climate and teacher's job satisfaction.

\begin{abstract}
Abstrak
Penelitian ini bertujuan untuk mengeksplorasi kontribusi komitmen kerja dan iklim sekolah terhadap kepuasan kerja guru. Dengan menggunakan metode korelasional yang dianalisis dengan teknik korelasi dan regresi, penelitian menunjukkan bahwa komitmen kerja berkontribusi secara signifikan terbadap kepuasan kerja guru. Ini berarti babwa komitmen kerja dapat digunakan sebagai prediktor untuk kepuasan kerja guru. Kemudian iklim sekolab berkontribusi secara signifikan terhadap kepuasan kerja guru juga. Hasil ini berarti bahwa iklim sekolah dapat digunakan sebagai prediktor untuk kepuasan kerja guru. Komitmen terhadap iklim kerja dan sekolab berkontribusi secara signifikan terhadap kepuasan kerja guru. Kepuasan kerja guru dipengarubi oleb komitmen kerja dan iklim sekolah, baik secara individu maupun bersama. Selanjutnya, komitmen tinggi dan juga didukung oleh iklim sekolah menciptakan kondusif dan meningkatkan kepuasan kerja guru. Komitmen terhadap iklim kerja dan sekolah merupakan dua faktor yang sangat penting karena dapat mempengarubi kepuasan kerja, namun ada beberapa faktor lain yang diyakini berpengaruh pada kepuasan kerja guru.
\end{abstract}

Kata Kunci: komitmen kerja, iklim sekolah, kepuasan kerja guru

Permalink/DOI: http://dx.doi.org/10.18326/infsl3v12i2.417-434 


\section{Pendahuluan}

Ketika seseorang bekerja pada suatu organisasi, instansi atau perusahaan maka hasil kerja yang dia selesaikan akan mempengaruhi terhadap produktifitas organisasi. Oleh karena itu, pandangan dan juga perasaan individu terhadap pekerjaannya harus tetap terjaga pada sisi positif dari pekerjaannya dengan kata lain individu tersebut harus memiliki dan menjaga kepuasan kerjanya agar produktifitasnya dapat terus ditingkatkan. Secara teoritis, kepuasan kerja merupakan salah satu faktor yang penting bagi individu dalam bekerja untuk mendapatkan hasil yang lebih optimal. Ketika seseorang merasakan kepuasan dalam bekerja, tentunya dia akan berupaya semaksimal mungkin dengan segenap kemampuan yang dimilikinya untuk menyelesaikan tugas dan pekerjaannya dengan sebaik-baiknya.

Begitu juga dengan guru, jika guru memiliki kepuasan kerja yang tinggi maka akan dapat meningkatkan produktifitasnya. Mengingat begitu pentingnya kedudukan kepuasan kerja guru, pemerintah sebagai penanggung jawab utama penyelenggaraan pendidikan telah melakukan berbagai upaya untuk meningkatkan kepuasan kerja guru. Salah satu upaya yang telah dilakukan oleh pemerintah untuk meningkatkan kepuasan kerja guru ini salah satunya adalah melalui peningkatan terhadap kesejahteraan guru (Kartowagiran, 2011). Namun, usaha tersebut belum dapat meningkatkan kepuasasan kerja guru ke arah yang diharapkan.

Sarjana (2012) menjelaskan jika kepuasan kerja guru belum terpenuhi maka dikhawatirkan akan mengakibatkan munculnya ketidakseriusan guru dalam menjalankan tugasnya. Ketidakpuasan guru ini selanjutnya akan berdampak pada timbulnya permasalahan baru seperti guru indisipliner. Dalam hal ini, gejala-gejala yang mencerminkan rendahnya kepuasan kerja guru ini diduga akan mempengaruhi produktivitas kerja, oleh karena itu perlu ditanggulangi secara tepat supaya tidak mengganggu proses pencapaian tujuan pendidikan.

Guru sebagai salah satu faktor penting dalam penyelenggaraan pendidikan di sekolah haruslah memperoleh kepuasan kerja yang tinggi dalam melaksanakan tugasnya, semakin baik tingkat kepuasan kerja guru semakin baik motivasi dan prestasi kerja. Gistituati (2009) 
menyatakan bahwa faktor-faktor yang mempengaruhi kepuasan kerja seseorang adalah pekerjaan itu sendiri, gaji, promosi, pengawasan, kelompok kerja dan kondisi kerja. Robbins (2003) juga mengemukakan bahwa kepuasan kerja seseorang dipengaruhi oleh pekerjaan yang secara mental menantang, ganjaran yang pantas, iklim organisasi, rekan kerja yang mendukung, serta kesesuaian kepribadian dengan pekerjaan. Winardi (2001) menyatakan bahwa ada dua faktor yang mempengaruhi prilaku manusia yaitu faktor bygiene yang keberadaannya bisa menghilangkan ketidakpuasan dan faktor motivator yang mampu menimbulkan kepuasan kerja.

Farida, Iqbal dan Kurniasih (2016) mengungkapkan bahwa komitmen kerja merupakan kecenderungan dalam diri seseorang untuk merasa terlibat aktif dengan penuh tanggung jawab dalam pelaksanaan suatu pekerjaan. Jika komitmen telah tertanam dalam diri seseorang maka hal ini akan dapat secara langsung meningkatkan kepuasan kerja tersendiri bagi guru dalam menjalankan tugas dan tangggung jawabnya.

Disiplin Kerja adalah kepatuhan untuk menghormati dan melaksanakan suatu sistem yang mengharuskan orang-orang tunduk pada putusan, perintah, atau peraturan yang berlaku. Machwati dan Wibowo (2015) mngatakan guru yang pada dirinya terdapat kesadaran akan adanya aturan dan melaksanakan aturan secara total maka pekerjaan guru tersebut cenderung akan optimal, dan hasil pekerjaan ini akan berdampak pada kepuasan kerja guru tersebut, dan begitu juga sebaliknya.

Prihatin (2016) menjelaskan gaji dan insentif juga diduga ikut mempengaruhi kepuasan kerja guru. Seorang pekerja mengharapkan gaji atau insentif yang sesuai dengan jenis dan beban pekerjaan yang diembannya. Begitu juga dengan guru di sekolah, apabila gaji atau insentif yang diterimanya sesuai dengan beban pekerjaan yang dilakukannya dan gaji tersebut dapat memenuhi kebutuhan hidupnya, guru akan puas dan akan lebih bersemangat dalam bekerja.

Selain itu, guru dalam melaksanakan tugasnya sebagai pendidik dan pengajar membutuhkan rasa aman. Rasa aman yang diperoleh guru dalam melaksanakan tugas, diduga akan ikut 
memberikan pengaruh yang positif terhadap kepuasan kerja guru. Iklim sekolah berhubungan dengan suasana kerja yang terjadi dalam suatu sekolah yang tercipta oleh pola hubungan antar individu di dalamnya. Handayani dan Rasyid (2015) menyatakan iklim sekolah yang kondusif menjadikan hubungan antar sesama guru, dan guru dengan kepala sekolah menjadi lebih harmonis.

Hoy, W.K. dan Miskel, (2001), Gistituati (2009), Muhammad (2011) menyatakan bahwa iklim sekolah adalah suatu situasi atau suasana internal organisasi sekolah yang dirasakan oleh orangorang yang ada di sekolah. Dalam melaksanakan tugasnya sebagai seorang pendidik, guru membutuhkan iklim sekolah yang kondusif dan harmonis. Sastrohadiwiryo (2005) menjelaskan bahwa iklim sekolah yang kurang kondusif akan memberi dampak negatif bagi guru. Oleh karena itu maka perlu dilakukan pemeliharaan supaya iklim sekolah dapat berjalan aman dan nyaman, sehingga mampu memberikan ketenangan dan kenyamanan bagi guru dalam bekerja.

Untuk mewujudkan iklim yang kondusif di sekolah, kepemimpinan kepala sekolah sangat menentukan. Apabila pemimpin dapat menjalankan tugasnya dengan baik maka iklim yang kondusif akan tercipta, jika iklim sekolah harmonis dapat memberikan dampak yang positif terhadap terciptanya kepuasan kerja guru. Mangkunegara dan Puspitasari (2015) menegaskan bahwa prestasi kerja guru yang mendapat perhatian akan memberikan kepuasan kerja bagi guru yang bersangkutan. Mereka tentu akan merasa puas melihat hasil kerja kerasnya ternyata tidak sia-sia. Sutrisno (2010) menyatakan bahwa kepuasan kerja penting untuk mengaktualisasikan diri, mencapai kedewasaan psikologis, menghindari diri dari frustasi, dan mendorong seseorang menyukai pekerjaannya, serta mendorong untuk lebih kreatif. Rivai (2006) menyatakan bahwa kepuasan kerja yang dirasakan guru akan membawa pengaruh terhadap pekerjaan yang dilakukannya.

Komitmen kerja, iklim sekolah serta kepuasan kerja guru sebagaimana yang dijelaskan di atas belum terlihat realisasinya di SMA Kecamatan IV Jurai Pesisir Selatan, hal ini tergambar dari hasil observasi dan wawancara yang penulis lakukan pada tanggal 0914 September 2013 di SMA Negeri Kecamatan IV Jurai Kabupaten 
Pesisir Selatan. Berkaitan dengan komitmen kerja guru terlihat dari kurangnya kesadaran dan tanggung jawab guru dalam melaksanakan tugas yang diberikan kepadanya dan datang terlambat dari jam yang ditentukan, serta masih enggan sebagian guru menerima tugas tambahan diluar jam mengajar, dan kadangkala merasa terpaksa melaksanakan tugas yang seharusnya dilaksanakan. Iklmi sekolah yang ada di SMA tersebut juga terlihat kurang harmonis, hal ini terlihat dari kurang baiknya hubungan yang terjalin antar sesama guru, masih adanya rasa saling mencurigai diantara guru dengan personil sekolah lainnya. Dalam hal kepuasan kerja terlihat bahwa guru guru belum merasa puas dengan pekerjaannya, hal ini dapat dipahami dari pernyataan guru yang mengatakan bahwa dia tidak puas dalam proses pembelajaran karena kurang lengkapnya sarana dan prasarana, tugas mengajar yang tidak sesuai dengan bidang keilmuan, hasil kerja yang tidak dihargai, delegasi wewenang yang tidak jelas.

Dari paparan di atas dapat dipahami bahwa permasalahan yang terjadi di SMA Negeri Kecamatan IV Jurai Kabupaten Pesisir Selatan adalah sesuatu yang perlu diungkapkan, untuk itu penelitian ini ingin mengkaji permasalahan tersebut dengan melihat korelasi anatara komitmen kerja, iklim sekolah dengan kepuasan kerja.

\section{Metode Penelitian}

Penelitian ini menggunakan metode kuantitatif dengan jenis penelitian korelasional karena penelitian ini bertujuan untuk melihat hubungan antara satu variabel dengan variabel yang lainnya. Variabel penelitian ini dibedakan atas dua kelompok yaitu variabel bebas dan variabel terikat. Variabel bebas adalah komitmen kerja dan iklim sekolah, sedangkan variabel terikat adalah kepuasan kerja guru. Dengan demikian penelitian ini mengungkapkan besarnya kontribusi komitmen kerja dan iklim sekolah terhadap kepuasan kerja guru.

Instrumen yang digunakan untuk mengumpulkan data ketiga variabel penelitian ini adalah angket model skala likert dengan lima alternatif jawaban yaitu: selalu (SL), sering (SR), kadang-kadang 
(KD), jarang (JR), dan tidak pernah (TP). Penyusunan instrumen pada masing-masing variabel dilakukan dengan langkah-langkah sebagai berikut: 1) pembuatan kisi-kisi instrumen berdasarkan indikator variabel, 2) menyusun butir-butir pertanyaan-pertanyaan yang sesuai dengan indikator, 3) melakukan analisis rasional untuk melihat kesesuaian dengan indikator serta ketepatan penyusunan angket dari segi bahasa dan aspek yang di ukur.

Adapun teknik analis yang digunakan ialah bahwa data penelitian dianalisis dengan menggunakan teknik regresi dan korelasi. Analisis dilakukan dengan bantuan komputer program SPSS for windows versi 18.00. Berikut langkah-langkah analisis tersebut:

Analisis Deskriptif

Analisis deskriptif bertujuan untuk mengetahui kecenderungan distribusi frekuensi variabel dan menentukan tingkat ketercapaian responden pada masing-masing variabel. Tingkat pencapaian responden pada masing-masing variabel akan diketahui melalui rumus:

Tingkat Pencapaian Skor=

$$
\frac{\text { Skor rata }- \text { rata }}{\text { Skor maksimal ideal }} \times 100 \%
$$

Tingkat ketercapaian masing-masing variabel berguna untuk menggambarkan pencapaian responden secara kualitatif pada masing-masing variabel. Adapun kriteria yang digunakan untuk melihat tingkat pencapaian responden digunakan klasifikasi Sudjana (1982), seperti berikut ini.

Kategori Tingkat Ketercapaian Responden

\begin{tabular}{ll}
\hline Rentang Persentase & Kategori \\
\hline $90-100 \%$ & Sangat Baik \\
$80-89 \%$ & Baik \\
$65-79 \%$ & Cukup \\
$55-64 \%$ & Kurang baik \\
$0-54 \%$ & Tidak baik \\
\hline
\end{tabular}




\section{Hasil Penelitian}

\section{Kepuasan Kerja Guru}

Angket variabel kepuasan kerja guru terdiri dari 37 butir, maka skor minimum adalah 37 dan skor maksimum 185. Dari jawaban responden, diperoleh skor terendah adalah 120 dan skor tertinggi adalah 170 . Hasil pengolahan data diperoleh skor rata-rata (mean ) sebesar 143,40, modus (mode) sebesar 122,00, median sebesar 144,00 dan simpangan baku (standard deviation) sebesar 14,342 .

Tabel 1. Distribusi Frekuensi Skor Kepuasan Kerja Guru

\begin{tabular}{lllll}
\hline Kelas Interval & Fo & \%fo & Fk & \%fk \\
\hline $168-175$ & 2 & 3,08 & 2 & 3,08 \\
\hline $160-167$ & 8 & 12,31 & 10 & 15,38 \\
\hline $152-159$ & 11 & 16,92 & 21 & 32,31 \\
\hline $144-151$ & 14 & 21,54 & 35 & 53,85 \\
\hline $\mathbf{1 3 6}-\mathbf{1 4 3}$ & $\mathbf{9}$ & $\mathbf{1 3 , 8 5}$ & $\mathbf{4 4}$ & $\mathbf{6 7 , 6 9}$ \\
\hline $128-135$ & 8 & 12,31 & 52 & 80,00 \\
\hline $120-127$ & 13 & 20,00 & 65 & 100,00 \\
\hline Jumlah & $\mathbf{6 5}$ & $\mathbf{1 0 0}$ & & \\
\hline
\end{tabular}

Pada Tabel 1 kelihatan bahwa 13,85\% dari skor kepuasan kerja guru berada pada kelas interval skor rata-rata; 53,85\% skor kepuasan kerja guru berada di atas kelas interval skor rata-rata; dan 32,31\% berada di bawah kelas interval skor rata-rata. Ini berarti bahwa sebagian besar skor kepuasan kerja guru berada di atas kelas interval skor rata-rata. Selanjutnya untuk gambaran histogram variabel kepuasan kerja guru dapat dilihat pada Gambar 1 berikut. 


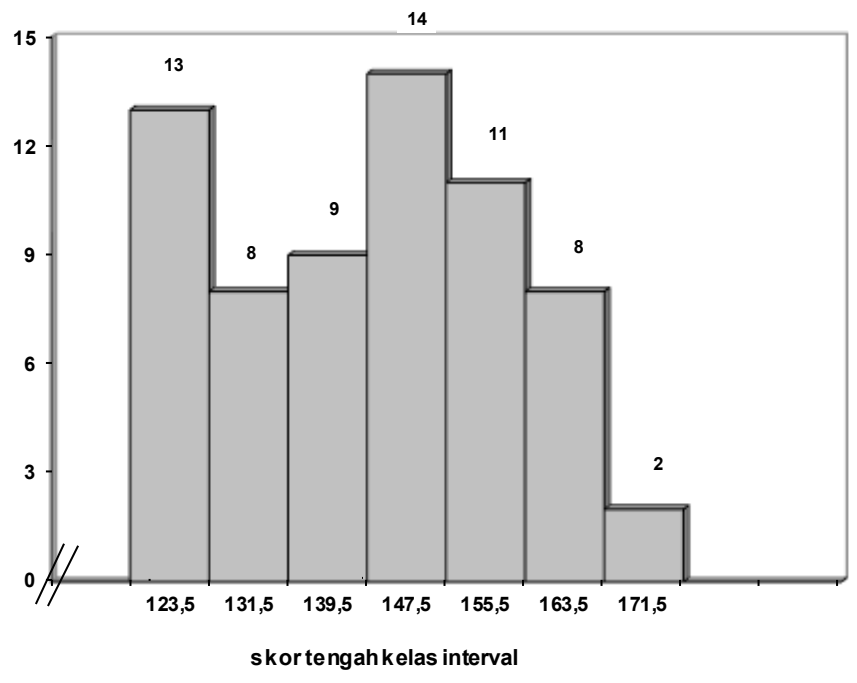

Gambar 1. Histogram Kepuasan Guru

Selanjutnya hasil analisis tingkat pencapaian responden untuk setiap indikator kepuasan kerja guru dapat dilihat pada Tabel 2.

\section{Tabel 2. Tingkat Pencapaian Respon untuk setiap Indikator Kepuasan Kerja Guru}

\begin{tabular}{llllll}
\hline No & Indikator & $\begin{array}{l}\text { Skor } \\
\text { Ideal }\end{array}$ & $\begin{array}{l}\text { Skor } \\
\text { Rata-Rata }\end{array}$ & $\begin{array}{l}\text { \%Tingkat } \\
\text { Pencapaian }\end{array}$ & Kategori \\
\hline 1 & Perasaan senang & 50 & 39,17 & 78,34 & Cukup \\
\hline 2 & Perasaan lega & 40 & 31,51 & 78,77 & Cukup \\
\hline 3 & Perasaan puas & 45 & 35,46 & 78,80 & Cukup \\
\hline 4 & $\begin{array}{l}\text { Tidak mengeluh terhadap } \\
\text { tantangan pekerjaan }\end{array}$ & 50 & 37,26 & 74,52 & Cukup \\
$\begin{array}{l}\text { Keseluruhan respon kepuasan } \\
\text { kerja guru }\end{array}$ & 185 & 143,40 & 77,51 & Cukup \\
\hline
\end{tabular}

Pada Tabel 2 kelihatan bahwa tingkat capaian rata-rata secara umum adalah 77,51\%. Tingkat capaian ini berada pada kategori cukup. Ini berarti bahwa secara umum dapat dikatakan kepuasan kerja guru SMA Negeri di Kecamatan IV Jurai dilihat dari 
aspek perasaan senang, perasaan lega, perasaan puas, serta tidak mengeluh terhadap tantangan pekerjaan masih cukup, dan perlu untuk ditingkatkan ke arah yang lebih baik. Tingkat capaian masingmasing indikator sama, yaitu cukup.

\section{Komitmen Kerja}

Angket variabel komitmen kerja terdiri dari 37 butir. Maka skor minimum adalah 37 dan skor maksimum 185. Dari jawaban responden, diperoleh skor terendah adalah 114 dan skor tertinggi adalah 168. Hasil pengolahan data diperoleh skor rata-rata (mean ) sebesar 144,71, modus (mode) sebesar 1594,00, median sebesar 147,00 dan simpangan baku (standard deviation) sebesar 15,089. Selisih skor rata-rata, modus, dan median tidak melebihi satu simpangan baku. Ini berarti bahwa distribusi frekuensi skor variabel komitmen kerja cenderung normal. Gambaran distribusi frekuensi skor komitmen kerja, dapat dilihat pada Tabel 3.

Tabel 3. Distribusi Frekuensi Skor Komitmen Kerja $\left(\mathbf{X}_{1}\right)$

\begin{tabular}{lllll}
\hline Kelas Interval & Fo & \%fo & Fk & \%fk \\
\hline $162-169$ & 9 & 13,85 & 9 & 13,85 \\
$154-161$ & 14 & 21,54 & 23 & 35,38 \\
$146-153$ & 10 & 15,38 & 33 & 50,77 \\
$\mathbf{1 3 8}-\mathbf{1 4 5}$ & $\mathbf{1 2}$ & $\mathbf{1 8 , 4 6}$ & $\mathbf{4 5}$ & $\mathbf{6 9 , 2 3}$ \\
$130-137$ & 8 & 12,31 & 53 & 81,54 \\
$122-129$ & 6 & 9,23 & 59 & 90,77 \\
$114-121$ & 6 & 9,23 & 65 & 100,00 \\
Jumlah & $\mathbf{6 5}$ & $\mathbf{1 0 0}$ & & \\
\hline
\end{tabular}

Pada Tabel 3 kelihatan bahwa 18,46\% dari skor komitmen kerja berada pada kelas interval skor rata-rata; 50,77\% skor komitmen kerja di atas kelas interval skor rata-rata; dan 30,77\% berada di bawah kelas interval skor rata-rata. Ini berarti bahwa sebagian besar skor komitmen kerja berada di atas kelas interval skor rata-rata. Selanjutnya untuk gambaran histogram skor variabel komitmen kerja dapat dilihat pada Gambar 2 berikut. 


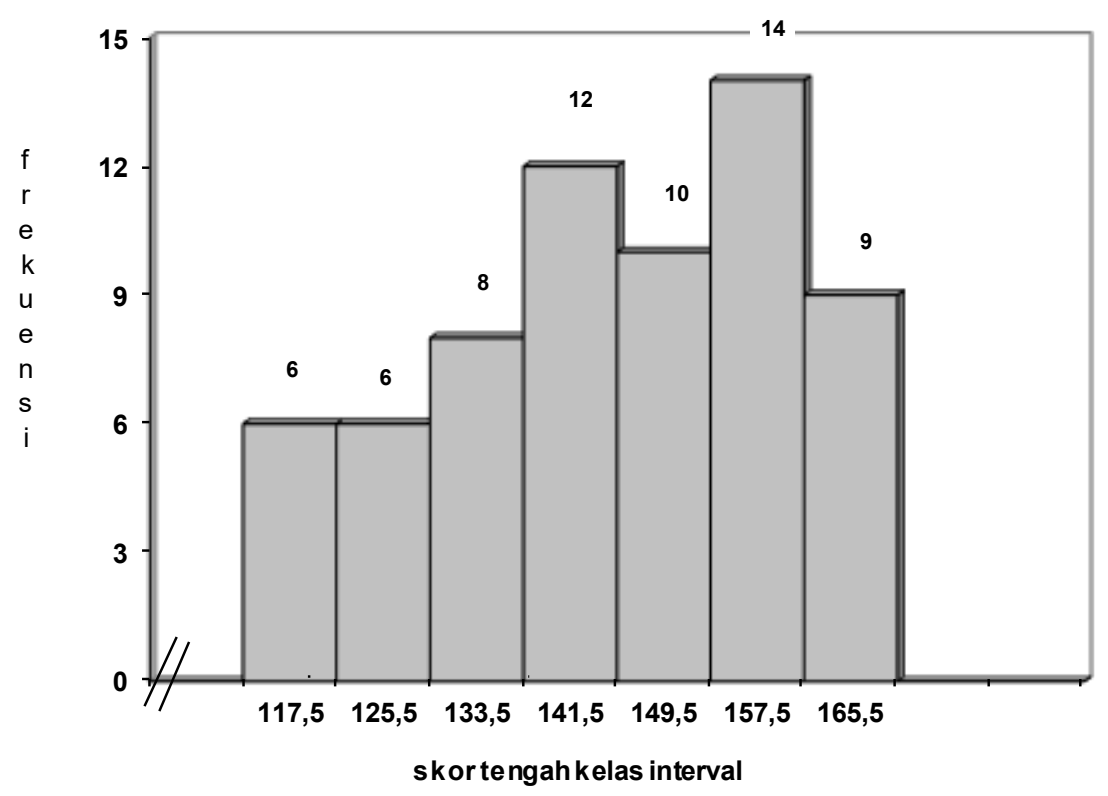

Gambar 2. Histogram Komitmen Kerja

Selanjutnya hasil analisis tingkat pencapaian responden untuk setiap indikator komitmen kerja dapat dilihat pada Tabel 4.

Tabel 4. Tingkat Pencapaian Respon untuk setiap Indikator Komitmen Kerja

\begin{tabular}{|c|c|c|c|c|c|}
\hline $\mathrm{No}$ & Indikator & $\begin{array}{l}\text { Skor } \\
\text { Ideal }\end{array}$ & $\begin{array}{l}\text { Skor } \\
\text { Rata-Rata }\end{array}$ & $\begin{array}{l}\text { \%Tingkat } \\
\text { Pencapaian }\end{array}$ & Kategori \\
\hline 1 & $\begin{array}{l}\text { Rasa bertanggung jawab } \\
\text { terhadap tugas }\end{array}$ & 50 & 39,45 & 78,89 & Cukup \\
\hline 2 & Loyalitas pada pekerjaan & 50 & 39,32 & 78,65 & Cukup \\
\hline 3 & $\begin{array}{l}\text { Rasa kepedulian terhadap } \\
\text { pekerjaan }\end{array}$ & 50 & 39,38 & 78,77 & Cukup \\
\hline 4 & Berdisiplin dalam bekerja & 35 & 26,55 & 75,87 & Cukup \\
\hline \multicolumn{2}{|c|}{$\begin{array}{l}\text { Keseluruhan respon } \\
\text { komitmen kerja }\end{array}$} & 185 & 144,71 & 78,22 & Cukup \\
\hline
\end{tabular}


Pada Tabel 4 kelihatan bahwa tingkat capaian rata-rata secara umum adalah 78,22\%. Tingkat capaian ini berada pada kategori cukup. Ini berarti bahwa secara umum dapat dikatakan komitmen kerja guru SMA Negeri di Kecamatan IV Jurai dilihat dari aspek rasa bertanggung jawab terhadap tugas, loyalitas pada pekerjaan, rasa kepedulian terhadap pekerjaan, dan berdisiplin dalam bekerja masih cukup dalam pelaksanaannya. Analisis perindikator juga memperlihatkan bahwa tingkat capaian semua indikator sama, yaitu berada pada kategori cukup.

\section{Iklim Sekolah}

Angket variabel iklim sekolah terdiri dari 37 butir. Maka skor minimum adalah 37 dan skor maksimum 185. Dari jawaban responden, diperoleh skor terendah adalah 114 dan skor tertinggi adalah 168. Hasil pengolahan data diperoleh skor rata-rata (mean) sebesar 144,78, modus (mode) sebesar 139,00 median sebesar 148,00 dan simpangan baku (standard deviation) sebesar 15,163. Selisih skor rata-rata, modus, dan median tidak melebihi satu simpangan baku. Ini berarti bahwa distribusi frekuensi skor variabel iklim sekolah cenderung normal. Gambaran distribusi frekuensi skor iklim sekolah, dapat dilihat pada Tabel 5.

Tabel 5. Distribusi Frekuensi Skor Iklim sekolah

\begin{tabular}{lllll}
\hline Kelas Interval & Fo & \%fo & $\mathbf{f k}$ & \%fk \\
\hline $162-169$ & 9 & 13,85 & 9 & 13,85 \\
$154-161$ & 12 & 18,46 & 21 & 32,31 \\
$146-153$ & 14 & 21,54 & 35 & 53,85 \\
$\mathbf{1 3 8}-\mathbf{1 4 5}$ & $\mathbf{1 0}$ & $\mathbf{1 5 , 3 8}$ & $\mathbf{4 5}$ & $\mathbf{6 9 , 2 3}$ \\
$130-137$ & 7 & 10,77 & 52 & 80,00 \\
$122-129$ & 7 & 10,77 & 59 & 90,77 \\
$114-121$ & 6 & 9,23 & 65 & 100,00 \\
Jumlah & $\mathbf{6 5}$ & $\mathbf{1 0 0}$ & & \\
\hline
\end{tabular}


Pada Tabel 5 terlihat bahwa 15,38\% dari skor iklim sekolah berada pada kelas interval skor rata-rata; $53,85 \%$ skor iklim sekolah berada di atas kelas interval skor rata-rata; dan 30,77\% berada di bawah kelas interval skor rata-rata. Ini berarti bahwa sebagian besar skor iklim sekolah berada di atas kelas interval skor rata-rata. Selanjutnya untuk gambaran histogram skor variabel iklim sekolah dapat dilihat pada Tabel 5 .

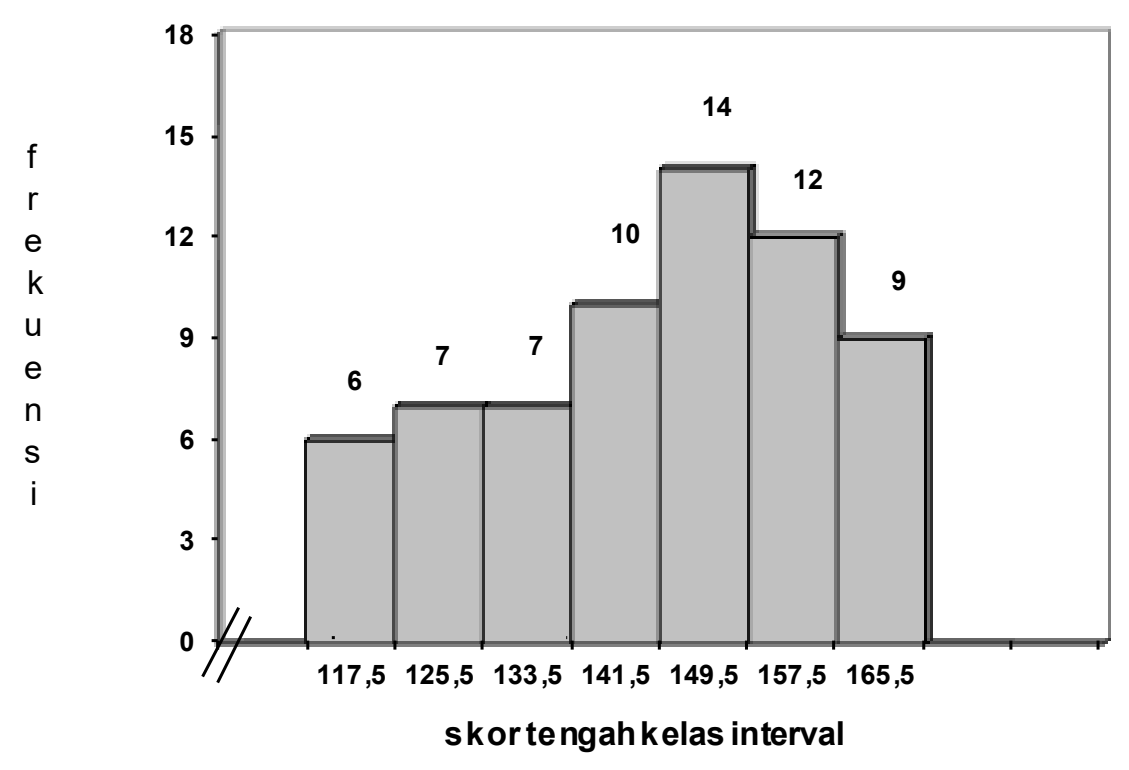

Gambar 3. Histogram Iklim Sekolah

Selanjutnya hasil analisis tingkat pencapaian responden untuk setiap indikator iklim sekolah dapat dilihat pada Tabel 6. 


\section{Tabel 6. Tingkat Pencapaian Respon untuk setiap Indikator Iklim Sekolah}

\begin{tabular}{llllll}
\hline No Indikator & $\begin{array}{l}\text { Skor } \\
\text { Ideal }\end{array}$ & $\begin{array}{l}\text { Skor } \\
\text { Rata-Rata }\end{array}$ & $\begin{array}{l}\text { \%Tingkat } \\
\text { Pencapaian }\end{array}$ & Kategori \\
\hline 1 & $\begin{array}{l}\text { Keterbukaan antara guru } \\
\text { dengan kepala sekolah }\end{array}$ & 35 & 26,52 & 75,78 & Cukup \\
\hline 2 & $\begin{array}{l}\text { Keakraban yang terjadi antara } \\
\text { pribadi personil sekolah }\end{array}$ & 40 & 31,54 & 78,85 & Cukup \\
\hline 3 & $\begin{array}{l}\text { Sikap saling menghargai antara } \\
\text { sesama personil sekolah }\end{array}$ & 30 & 23,65 & 78,82 & Cukup \\
\hline 4 & $\begin{array}{l}\text { Kerjasama yang positif dalam } \\
\text { organisasi sekolah }\end{array}$ & 40 & 31,52 & 78,81 & Cukup \\
\hline 5 & $\begin{array}{l}\text { Lebih mengutamakan } \\
\text { kepentingan bersama }\end{array}$ & 40 & 31,55 & 78,88 & Cukup \\
\hline Keseluruhan respon iklim sekolah & 185 & 144,78 & 78,26 & Cukup \\
\hline
\end{tabular}

Pada Tabel 6 kelihatan bahwa secara umum tingkat pencapaian skor iklim sekolah adalah $78,26 \%$ kategori cukup. Hal ini menunjukkan bahwa iklim sekolah yang berlangsung di SMA di Kecamatan IV Jurai Kabupaten Pesisir Selatan dilihat dari aspek keterbukaan antara guru dengan kepala sekolah, keakraban yang terjadi antara pribadi personil sekolah, sikap saling menghargai antara sesama personil sekolah, dan kerjasama yang positif dalam organisasi sekolah, serta lebih mengutamakan kepentingan bersama masih cukup dalam pelaksanaannya. Tingkat capaian masingmasing indikator sama, yaitu cukup.

\section{Pembahasan}

Berdasarkan hasil penelitian yang sudah dijelaskan bahwa Komitmen kerja memberikan kontribusi sebesar 31,9\% terhadap kepuasan kerja guru SMA Negeri di Kecamatan IV Jurai. Artinya, kepuasan kerja 
guru ikut dipengaruhi oleh komitmen kerja sebesar 31,9\%, maka untuk meningkatkan kepuasan kerja guru dapat dilakukan melalui peningkatan terhadap komitmen kerja. Hal ini mengisyaratkan bahwa komitmen kerja merupakan faktor yang sangat penting dan perlu diperhatikan dalam peningkatan kepuasan kerja guru SMA Negeri Kecamatan IV Jurai Kabupaten Pesisir Selatan. Selanjutnya hasil analisis deskripsi data menunjukkan bahwa komitmen kerja guru SMA Negeri di Kecamatan IV Jurai Kabupaten Pesisir Selatan masih berada pada kategori cukup, dengan ketercapaian skor sebesar 78,22\% dari skor ideal.

Hasil penelitian juga menunjukkan bahwa Iklim sekolah berkontribusi sebesar 11,6\% terhadap kepuasan kerja guru SMA Negeri Kecamatan IV Jurai Kabupaten Pesisir Selatan. Ini berarti dengan adanya iklim sekolah yang kondusif, maka kepuasan kerja guru cenderung akan meningkat. Hal ini mengisyaratkan bahwa iklim sekolah merupakan faktor yang sangat penting dan perlu diperhatikan dalam peningkatan kepuasan kerja guru SMA Negeri Kecamatan IV Jurai Kabupaten Pesisir Selatan. Selanjutnya hasil analisis deskripsi data variabel iklim sekolah di SMA Negeri Kecamatan IV Jurai Kabupaten Pesisir Selatan secara umum diketahui masih berada pada kategori cukup dengan skor 78,26\% dari skor ideal. Selanjutnya dilihat dari tingkat capaian perindikatornya, diketahui bahwa semua indikator masih berada pada kategori cukup.

Dengan demikian Komitmen kerja dan iklim sekolah secara bersama-sama memberikan kontribusi yang berarti (38,0\%) terhadap kepuasan kerja guru SMA Negeri di Kecamatan IV Jurai Kabupaten Pesisir Selatan. Hal ini menggambarkan bahwa bila komitmen kerja guru tinggi dan didukung pula oleh iklim sekolah yang kondusif maka kepuasan kerja guru cenderung meningkat. Ini mengisyaratkan bahwa untuk meningkatkan kepuasan kerja guru yang tinggi, sebaiknya dilakukan melalui komitmen kerja guru dan iklim sekolah yang kondusif. Dilihat dari hasil analisis deskripsi data variabel kepuasan kerja guru SMA Negeri Kecamatan IV Jurai Kabupaten Pesisir Selatan diketahui berada pada kategori cukup dengan tingkat capaian skor sebesar 77,51\% dari skor ideal. Selanjutnya dilihat dari tingkat capaian perindikatornya, diketahui bahwa semua indikator masih berada pada kategori cukup. 
Hasil penelitian ini menunjukkan bahwa komitmen kerja dan iklim sekolah berkontribusi signifikan terhadap kepuasan kerja guru, baik secara sendiri-sendiri maupun secara bersama-sama. Ini berarti bahwa kepuasan kerja guru dapat ditingkatkan menjadi lebih baik melalui peningkatan terhadap komitmen kerja serta iklim sekolah. Oleh karena itu, faktor utama yang perlu menjadi perhatian kepala sekolah dan pihak yang terkait dalam meningkatkan kepuasan kerja guru adalah melakukan peningkatan terhadap komitmen kerja guru dan iklim sekolah.

Peningkatan komitmen kerja guru ini pada dasarnya dapat dilakukan melalui indikator yang tingkata capaian responnya terendah. Berdasarkan hasil analisis diketahui bahwa berdisiplin dalam bekerja merupakan indikator dari komitmen kerja yang tingkat capaian responnya terendah. Oleh karena itu, perlu dilakukan sebuah upaya agar disiplin guru dalam bekerja dapat meningkat ke arah yang lebih baik. Upaya yang dapat dilakukan untuk meningkatkan disiplin guru ini diantaranya dapat dilakukan oleh guru itu sendiri dan oleh kepala sekolah selaku pimpinan. Adapun bentuk upaya yang dapat dilakukan oleh guru untuk meningkatkan kedisiplinannya dalam bekerja adalah dengan menanamkan sebuah kesadaran dan keyakinan dalam dirinya bahwa pekerjaan yang dilakukannya adalah sebuah amanah yang harus dijalankan dengan penuh tanggung jawab. Artinya, jika guru sudah memiliki keyakinan bahwa pekerjaan yang dilakukannya itu adalah sebuah amanah maka dia akan melakukannya dengan sebaik-baiknya dengan penuh rasa tanggung jawab dan tepat pada waktunya tanpa menunda pelaksanaan dari pekerjaan tersebut. Selain itu dengan membuat daftar pekerjaan berdasarkan skala prioritas diduga juga dapat meningkatkan kedisiplinan guru dalam bekerja. Selanjutnya, upaya berikutnya yang dapat dilakukan untuk meningkatkan kedisiplinan guru dalam bekerja supaya menjadi lebih baik lagi adalah melalui pengawasan terhadap setiap kegiatan atau pekerjaan yang dilakukan guru. Pengawasan ini dapat dilakukan oleh kepala sekolah selaku pimpinan. Artinya, kepala sekolah memiliki andil untuk meningkatkan disiplin kerja guru. Ini dikarenakan, secara ilmu psikologis diketahui bahwa kecenderungan seseorang akan menampilkan perilaku kerja yang 
baik apabila di dalam pelaksanaan pekerjaan tersebut ia diawasi dengan seksama. Selanjutnya, selain melalui pengawasana, kepala sekolah juga dapat meningkatkan disiplin kerja guru supaya menjadi lebih baik lagi melalui penegakan aturan dan pemberian sanksi yang tegas bagi guru yang tidak disiplin. Ini berangkat dari pengamatan yang dilakukan di lapangan menemukan bahwa masih adanya guru yang tidak bekerja dengan baik dikarenakan selama ini mereka tidak mendapatkan teguran atau bahkan sanksi dari kepala sekolah terhadap kelalaian (ketidakdisiplinan) yang mereka lakukan dalam bekerja. Dengan demikian dapat dipahami bahwa jika kepala sekolah dapat melakukan pengawasan dengan seksama terhadap guru dan didukung pula oleh penegakan aturan dan sanksi yang tegas bagi guru yang melanggar maka akan dapat memperbaiki atau meningkatkan disiplin guru dalam bekerja ke arah yang lebih baik.

Selanjutnya, untuk meningkatkan kepuasan kerja guru seperti yang telah dikemukakan sebelumnya dapat pula dilakukan melalui iklim sekolah. Upaya untuk meningkatkan iklim sekolah dapat dilakukan dengan berbagai cara. Salah satunya adalah melalui indikator yang tingkat capaian responnya terendah. Hasil analisis menunjukkan bahwa keterbukaan antara guru dengan kepala sekolah merupakan indikator dari variabel iklim sekolah yang tingkat capaian responnya terendah. Oleh karena itu sasaran utama yang harus diperbaiki agar iklim sekolah dapat berlangsung dengan baik adalah keterbukaan antara guru dengan kepala sekolah. Keterbukaan antara guru dengan kepala sekolah ini dapat terjadi dengan baik apabila kedua belah pihak membiasakan diri untuk selalu bersikap dan berkata jujur. Diharapkan dengan adanya kejujuran antara sesama guru dengan kepala sekolah, maka keterbukaan dapat tumbuh dengan baik. Selanjutnya, jika keterbukaan antara guru dan kepala sekolah terjalin dengan baik maka secara tidak langsung hal ini pun akan berpengaruh pada terciptanya rasa saling percaya diantara kedua belah pihak. Jika kepercayaan sudah terbangun maka hal ini pun akan berdampak positif pada iklim sekolah. Artinya, jika keterbukaan dapat tumbuh dengan baik, ini berarti iklim sekolah di SMA Negeri Kecamatan IV Jurai pun akan menjadi baik. Dengan demikian dapat dipahami bahwa jika iklim sekolah sudah berlangsung dengan kondusif/baik 
maka secara langsung kepuasan kerja guru SMA Negeri Kecamatan IV Jurai pun akan berlangsung dengan baik pula. Ini dikarenakan hasil penelitian menunjukkan bahwa iklim sekolah berkontribusi terhadap peningkatakan kepuasan kerja guru. Dengan demikian dapat dinyatakan bahwa upaya untuk meningkatkan komitmen kerja guru dan iklim sekolah dapat pula meningkatkan kepuasan kerja guru SMA Negeri di Kecamatan IV Jurai.

\section{Kesimpulan}

Berdasarkan Hasil analisis data dan pembahasan menunjukkan bahwa, komitmen kerja berkontribusi secara signifikan terhadap kepuasan kerja guru Ini berarti bahwa komitmen kerja bisa digunakan sebagai alat untuk memprediksi kepuasan kerja guru. Iklim sekolah berkontribusi secara signifikan terhadap kepuasan kerja guru. Ini berarti bahwa Iklim sekolah bisa digunakan sebagai alat untuk memprediksi kepuasan kerja guru. Komitmen kerja dan iklim sekolah secara bersama-sama berkontribusi secara signifikan terhadap kepuasan kerja guru. Kepuasan kerja guru dipengaruhi oleh komitmen kerja dan iklim sekolah, baik secara sendiri-sendiri maupun bersama-sama. Komitmen kerja yang tinggi dan didukung oleh iklim sekolah yang kondusif, dapat lebih meningkatkan kepuasan kerja guru menjadi lebih baik. Komitmen kerja dan iklim sekolah merupakan dua faktor yang sangat penting karena dapat mempengaruhi kepuasan kerja yang dimiliki oleh guru, akan tetapi ada faktor lain yang diduga ikut berpengaruh terhadap kepuasan kerja guru.

\section{Daftar Pustaka}

Farida, Syarifah Ida, Iqbal, Muhammad, dan Kurniasih, Augustina. (2016). Pengaruh Kepercayaan dan Komitmen Organisasi Terhadap Motivasi dan Kepuasan Kerja. Jurnal Kependidikan Penelitian Inovasi Pembelajaran, 46 (1), pp. 121-134.

Gistituati, Nurhizrah. (2009). Manajemen Pendidikan: Budaya dan Kepemimpinan Organisasi. Padang: UNP Press.

Handayani, Handayani, dan Rasyid, Aliyah A. (2015). Budaya Organisasi Terhadap Kinerja Guru SMA Negeri Wonosobo, 
Jurnal Akuntabilitas Manajemen Pendidikan, 3, (2), pp. 264277.

Hoy , W.K. dan Miskel CG. (2001). Administrasi Pendidikan: Teori, Riset, dan Praktik. Jakarta: Bumi Aksara.

Kartowagiran, Badrun. (2011). Kinerja Guru Profesional (Guru Pasca Sertifikasi), Cakrawala Pendidikan, XXX (3), pp. 463-473.

Machwati, Azzi, dan Wibowo, Udik Budi. (2015) Pengaruh Budaya Kerja, Kkomitmen, Motivasi Guru Terhadap Iklim Organisasi SD. Jurnal Akuntabilitas Manajemen Pendidikan, 3 (2), pp. 158-172.

Mangkunegara, A.A. Anwar Prabu dan Puspitasari, Mela. (2015). Kecerdasan Emosi, Stres Kerja, dan Kinerja Guru SMA. Jurnal Kependidikan Penelitian Inovasi Pembelajaran, 45 (2), pp. 142-155.

Muhammad, Arni. (2011). Komunikasi Organisasi. Jakarta: Bumi Aksara.

Prihatin, Suparno. (2016). Pengaruh Keadilan Kompensasi dan Kepuasan Kerja Guru Terhadap Komitmen Organiasasi Guru SMA Negeri 1 Weru Kabupaten Sukoharjo Tahun 2015. Jurnal Pendidikan dan Ekonomi, 5 (1), pp. 76-88.

Rivai, Veithzal. (2006). Kepemimpinan dan Perilaku Organisasi. Jakarta: PT. Raja Grafindo Persada.

Robbins, Stephen P. (2003). Perilaku Organisasi. Edisi Indonesia. Jakarta: Gramedia.

Sarjana, Sri. (2012), Pengaruh Supervisi dan Iklim Organisasi Terhadap Kepuasan Guru. Jurnal Kependidikan Penelitian Inovasi Pembelajaran, 42 (2), pp. 173-186.

Sastrohadiwiryo, B. Siswanto. (2005). Manajemen Tenaga Kerja Indonesiai: Pendekatan Administrasyif dan Operasional. Jakarta: Bumi Aksara.

Sudjana. (1982). Metoda Statistika. Bandung: Tarsito

Sutrisno, Edy. 2010. Manajemen Sumber Daya Manusia. Jakarta: Kencana.

Winardi. (2001). Motivasi dan Pemotivasian dalam Manajemen. Jakarta: Rajagrafindo Persada. 